\title{
Yüksek Basınç Saçtırma Yönteminin Yoğunluk Modülasyonlu İTO İnce Filmlerin Optik Özelliklerine Etkisinin İncelenmesi
}

\author{
Filiz KELEŞ ${ }^{1,2 *}$,Emre KARTAL, ${ }^{1,2}$ Ayşe SEYHAN ${ }^{1,2}$
}

${ }^{1}$ Niğde Ömer Halisdemir Üniversitesi, Fen Edebiyat Fakültesi, Fizik Bölümü, NİĞDE

${ }^{2}$ Niğde Ömer Halisdemir Üniversitesi Nanoteknoloji Uygulama ve Araştırma Merkezi, NİĞDE

*fkeles@ohu.edu.tr

\begin{abstract}
Öz: Verimli bir Si-tabanlı güneş hücresi için yüksek geçirgenliğe sahip saydam iletken elektrot kullanmak önemli bir ayrıntıdır. Bu amaçla kullanılan indiyum kalay oksit (ITO) aynı zamanda yansıma önleyici kaplama görevini de yerine getirir. Bu çalışmada, alçak basınç püskürtme (ABP) ve yüksek basınç püskürtme (YBP) yöntemleri ile üretilen farklı malzeme yoğunluklarına sahip iki katmanın bir araya getirilmesi ile oluşturulan yoğunluk modülasyonlu İTO ince filmlerin yansıma önleyici olarak davrandığı ve geçirgenliği düşürdüğü gösterilmiştir. YBP ile elde edilen İTO ince filmin üst tabaka olarak kullanıldığı durumda morfolojisinin daha pürüzlü hale geldiği ve her kalınlık değeri için geçirgenliğin daha yüksek olduğu gözlemlenmiştir. Buna bağlı olarak, bu numunelerde çok yönlü yansımanın daha düşük olduğu gösterilmiştir. YBP-İTO katmanın üzerine sentezlenen nanoyapıların oldukça homojen olması ayrıca bir avantajdır. Sonuç olarak, YBP yöntemi daha kullanışı bir İTO katmanı üretimi için basit ama etkili bir yöntem olduğunu ispatlamıştır.
\end{abstract}

Anahtar Kelimeler: İndiyum Kalay Oksit (İTO), Yoğunluk Modülasyonlu İnce Film, Optik Özellik, Yüksek Basınç Püskürtme (YBP), Silisyum Nanoyapı

\section{Investigation of The Effect of High Pressure Sputter Method on Optical Properties of Density Modulated ITO Thin Films}

\footnotetext{
Abstract: Having a high quality transparent conductive electrode is one of the critical parameters for high efficient Si-based photovoltaic device. Indium tin oxide (ITO), used for this purpose, also behaves as an anti-reflective coating. In this study, it was shown that the density modulated ITO thin films obtained by the combination of the low pressure sputter (LPS) and high pressure sputter (HIPS) layers behave anti-reflective coating as improve the transmission. The density modulated thin film whose upper layer was grown by HIPS has shown a more porous morphology and lower transmission for all thickness values. Besides, it was also observed that the omnidirectional reflection is lower. Additionally, the more homogenous property of the synthesized silicon nanostructures on HIPS-ITO is another beneficial finding. Thus, HIPS has claimed that it is a simple yet effective way of producing more efficient ITO layer
}

Keywords: Indium Tin Oxide (ITO), Density Modulated Thin Film, Optical Properties, High Pressure Sputter (HIPS), Silicon Nanostructure

\footnotetext{
*Corresponding author / Sorumlu yazar. Tel.: 0552238 3645; e-mail / e-posta: fkeles@ohu.edu.tr
} 


\section{Giriş}

Günümüz fotovoltaik teknolojisinde, hücre yapısının basit olması ve üretimin düşük sıcaklıkta yapılabilmesi avantajlarının yanı sıra veriminin de yüksek olması sebebi ile heteroeklem katkısız ince film silisyum (Si-HİT) güneş hücreleri son derece popülerdir (Yoshikawa ve ark., 2017; Masuko ve ark., 2014). Silisyum soğurma katmanı gibi diğer önemli bir katman olan saydam iletken elektrotun (TCE) da yüksek kalitede üretilmesi hücre verimliliğinin artırılmasında önemli rol oynar. Pencere katmanı olarak da kullanılan bu tabaka yüksek 1ş1k geçirgenliğine sahip olması için oldukça saydam ve yüklü parçacıkların etkili bir şekilde elektrotlara iletilebilmesi için iletken olmalıdır (Gordon, 2000). Bu gereksinimleri karşılamak adına kullanılan en yaygın TCE'lardan birisi de indiyum, kalay ve oksijen üçlüsünün belirli oranlarda karışmasıyla meydana gelen üçlü bileşim indiyum kalay oksit (ITO) ince filmdir. Oldukça saydam ve iletken olan İTO aynı zamanda yansıma önleyici kaplama görevini de yerine getirdiği için Si-HITT güneş hücrelerinde sıç̧a kullanılır (Kim ve ark., 2016; Lien, 2010).

Güneş hücresinin verimliliğinin artırılmasında gelen 1şı̆̆ın mümkün olan en az kayıpla hücreye iletilmesi önemlidir. Bu sebeple hücre yüzeyinden yansımayı azaltmaya yönelik yansıma önleyici kaplama (Schirone ve ark., 1997), yüzey şekillendirme (Zhong ve ark., 2013) ve nanoyapı üretimi (Tsakalakos ve ark., 2007) gibi bazı uygulamalar da güneş hücresi üretiminde yaygın şekilde kullanılır. Si-HİT güneş hücresi bu amaç doğrultusunda yüzeyi şekillendirilmiş $\mathrm{Si}$ alttaş üzerine ve hem TCE hem de yansıma önleyici kaplama görevlerini yerine getiren İTO kullanılarak üretilir. Si-HİT güneş hücresinde üst katmanda nanoyapı üretimi istenmeyen optik kayıları azaltmaya yönelik bir yöntemdir.

Optik kayıpları azaltmaya yönelik diğer basit ama etkili bir yöntem ise 1şılkla etkileşime giren üst tabaka ince filmin malzeme yoğunluğunu optimize ederek kırılma indisini düşürmektir. $\mathrm{Bu}$ sayede düşük kırılma indisine sahip bu üst katman herhangi bir ekstra işleme gerek duymaksızın yansıma önleyici kaplama (ARC) olarak davranır (Keles ve ark., 2017). $\mathrm{Bu}$ işlem basitçe ince film üretimi esnasında uygun parametrelerin seçimi ile gerçekleştirilebilir. Yüksek basınç püskürtme (YBP) yönteminin elde edilen filmin morfolojisini etkilediği ve optik özelliklerini iyileştirdiği gösterilmiştir (Keles ve ark., 2017; Keles ve ark., 2016). Püskürtme ile İTO ince film üretimi esnasında yoğun gaz kullanımı yüksek YBP olarak adlandirılır ve hedef atomlarının alttaşa daha geniş bir açı ile ulaşması ile sonuçlanır. Bunun aksine, üretim esnasında daha az yoğun gaz kullanımı alçak basınç 
püskürtme (ABP) olarak adlandırılır ve hedef atomlarının alttaşa daha doğrudan ulaşmasını sağlar. ABP ve YBP yöntemleri şematik olarak Şekil 1'de gösterilmiştir. YBP ile üretilen ince filmler hedef atomlarının gaz atomları ile yüksek oranda çarpışmaları sonrasında alttaşa ulaşarak üretime katılmaları sayesinde daha gözenekli bir yapıya ve düşük malzeme yoğunluğuna sahip olur. Sonuç olarak, sadece malzeme yoğunluğunu düşürerek

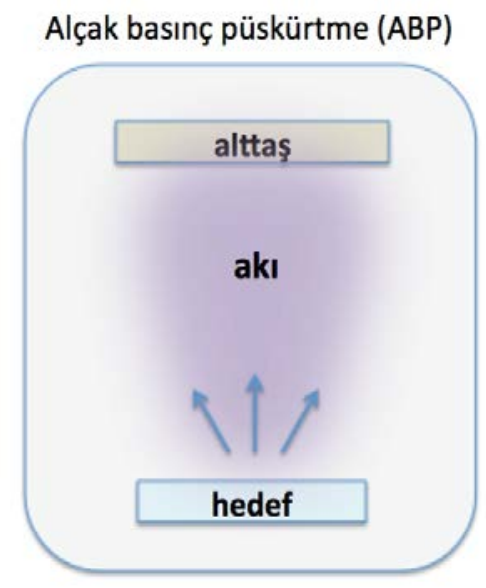

ince film yüzeyinden optik kayıpları azaltmak mümkün hale gelir. Bu çalışmada, ABP ve YBP yöntemlerinin beraber kullanılması ile elde edilen yoğunluk modülasyonuna sahip İTO ince filmlerin optik özelliklerinin nasıl değiştiği incelenmiştir. Ayrıca, yoğunluk modülasyonlu İTO ince film kaplamanın desenlendirilmiş $\mathrm{Si}$ alttaşı üzerine sentezlenen nanoyapıların morfolojisini nasıl etkilediği de incelenmiştir.

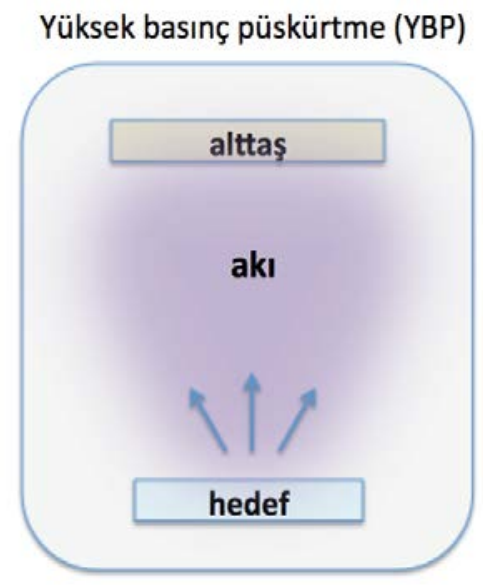

Şekil 1. Alçak basınç püskürtme (ABP, solda) ve yüksek basınç püskürtme (YBP, sağda) yöntemlerinin şematik gösterimi. ABP'de hedef atomları alttaşa daha doğrusal yoldan ulaşırken, YBP'de hedef atomları gaz atomları ile daha fazla çarpışmaya maruz kaldığından alttaşa daha geniş açılarda ulaşırlar.

\section{Materyal ve Yöntem}

\subsection{RF Magnetron Püskürtme ile} Yoğunluk Modülasyonlu İTO İnce Film

\section{Üretimi}

İTO ince filmi bir kaç farklı kaplama yöntemi ile gerçekleştirilebilir ancak kaplama esnasında uygun parametrelerin seçimi ile ince filmin istenilen özelliklerde üretilebilmesi avantajı sayesinde $\mathrm{RF}$ magnetron püskürtme oldukça tercih edilir
(Hussain ve ark., 2014; Gheidari ve ark., 2005; Zhao ve ark., 2005). Bu çalışmada da farklı kalınlık ve yoğunluk modülasyonuna sahip İTO ince filmlerin pürüzsüz $<100>$ yönelimli n-tipi Si, desenlendirilmiş <111> yönelimli n-tipi Si ve soda-kireç cam alttaşlar üzerine kaplama işlemi radyofrekanslı RF magnetron (13.6 MHz) püskürtme ile oda sicaklığında gerçekleştirilmiştir. Bütün kaplama işlemleri 100W RF gücü kullanılarak 
gerçekleştirilmiştir. Kaplama işlemi için \% 99.99 saflıktaki İTO $\left(\mathrm{In}_{2} \mathrm{O}_{3} ; \% 90\right.$ \& $\mathrm{SnO}_{2}$; \% 10) püskürtme hedefi kullanılmıştır ve kaplama basıncını ayarlamak için kullanılan Ar gazı dışında herhangi bir gaz kullanılmamıştır. Kazan taban basıncı yaklaşık 1 x $10^{-6}$ mTorr'a ulaştıktan sonra YBP ve ABP (Şekil 1) kaplamalar için sırası ile 24 mTorr'a ve 3 mTorr'a ayarlanır. ABP ile elde edilen ince film daha yoğun ve pürüzsüz olurken YBP sonucunda üretilen ince film düşük yoğunluğa sahip ve gözenekli olacaktır (Keles ve ark., 2017). Bu çalışmada, farklı malzeme özelliğine sahip bu iki ince film farklı kalınlık ve sıralamada birleştirilerek yoğunluk modülasyonlu İTO pencere katmanı oluşturulmuş ve optik özellikleri incelenmiştir. YBP ve ABP tabakaların her bir kalınlık değeri için numune üzerine üretimdeki öncelik ve sonralık sırası gözetilerek bir set oluşturulmuş ve bu set Çizelge 1'in son sütununda görüldüğü gibi isimlendirilmiştir. Ek olarak, numune üretimi için kullanılan üç farklı alttaş da $p$ - (pürüzsüz $\mathrm{Si}$ ), $d$ (desenlendirilmiş Si) ve $c$ - (soda-kireç cam) şeklinde kodlanmıştır. Üç farklı alttaş üzerine üretilen yoğunluk modülasyonlu İTO ince film numuneler hakkındaki detaylı bilgi Çizelge 1'de verilmiştir. Numuneleri üretmek için kullanılan NVTS-400 Isısal İşlem \& Püskürtme sistemi (Nanovak) Şekil 2'de gösterilmiştir.
İTO ince filmlerin morfolojik özellikleri taramalı elektron mikroskopu (SEM) ile incelenmiştir. SEM ölçümü için Si alttaşlar üzerine kaplanmış numuneler kullanılmıştır. Optik özellikleri incelemek için ise cam alttaşlar üzerine üretilmiş numunelerin yansıma ve geçirgenlik ölçümleri UV-VIS-NIR spektrumunda Elipsometre yardımı ile gerçekleştirilmiştir. Optik özellikleri gerçekleştirmek için 1şık doğrudan üst tabaka İTO ince filmin üzerine gönderilmiştir.

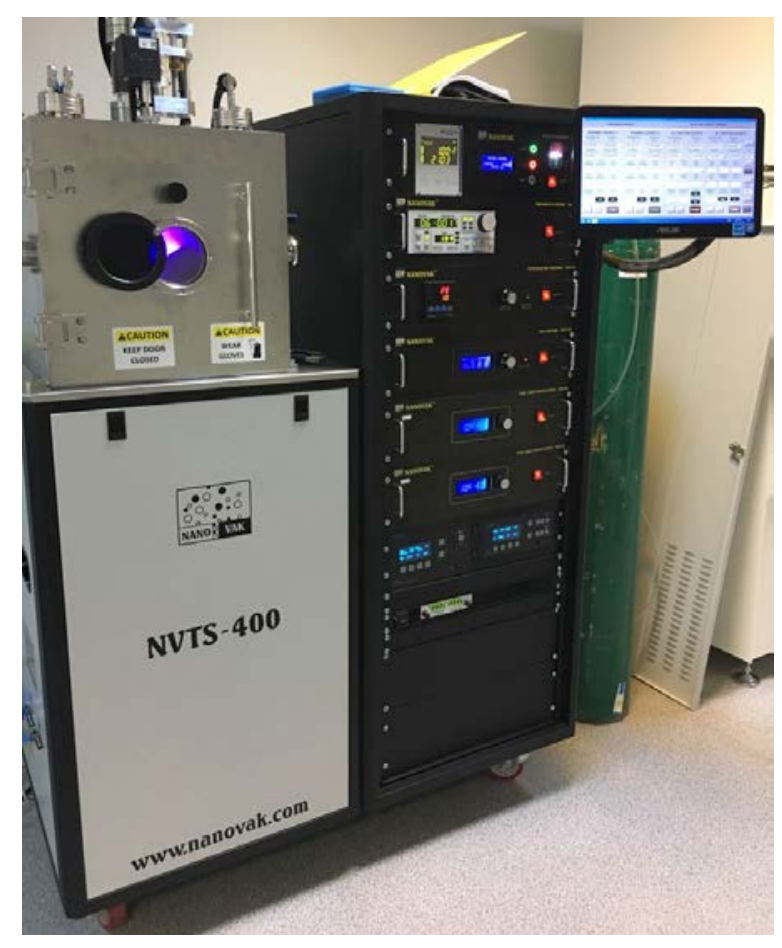

Şekil 2. Yoğunluk modülasyonlu İTO ince film numunelerin üretimi için kullanılan 1sısal işlem \& püskürtme sistemi. 
Çizelge 1. Yoğunluk modülasyonlu İTO ince film numuneleri.

\begin{tabular}{|l|c|c|c|}
\hline \multicolumn{1}{|c|}{ Numune ismi } & \multicolumn{2}{c|}{ ITO film kalını̆̆ $(\mathbf{n m})$} & $\begin{array}{c}\text { Tabakaların dizayn } \\
\text { (alttas üzerinden) }\end{array}$ \\
\hline $\boldsymbol{p}$-YA-70 \& $\boldsymbol{d}$-YA-70 \& $\boldsymbol{c}$-YA-70 & 70 & 70 & YBP-ÄB \\
\hline $\boldsymbol{p}$-AY-70 \& $\boldsymbol{d}$-AY-70 \& $\boldsymbol{c}$-AY-70 & 70 & 70 & ABP-YBP \\
\hline $\boldsymbol{p}$-YA-200 \& $\boldsymbol{d}$-YA-200 \& $\boldsymbol{c}$-YA-200 & 200 & 200 & YBP-ABP \\
\hline $\boldsymbol{p}$-AY-200 \& $\boldsymbol{d}$-AY-200 \& $\boldsymbol{c}$-AY-200 & 200 & 200 & ABP-YBP \\
\hline $\boldsymbol{p}$-YA-330 \& $\boldsymbol{d}$-YA-330 \& $\boldsymbol{c}$-YA-330 & 330 & 330 & YBP-ABP \\
\hline $\boldsymbol{p}$-AY-330 \& $\boldsymbol{d}$-AY-330 \& $\boldsymbol{c}$-AY-330 & 330 & 330 & ABP-YBP \\
\hline
\end{tabular}

Metal-Destekli Kimyasal Așındırma Yöntemi ile Nanoyapı Elde Edilmesi

Güneş hücrelerinde yüzeyden yansımayı azaltarak daha etkili bir şekilde 1şı̆̆ı soğurmak ve dolayısı ile verimliliği artırmak amacı ile kullanılan en yaygın yöntemlerden birisi de nanoyapı kullanmaktadır (Tsakalakos ve ark., 2007; Ferry ve ark., 2008; Conibeer ve ark., 2006). Silisyum tabanlı güneş hücrelerinde ise nanoyapı kullanımı verimliliği artırmanın yanı sıra daha az malzeme kullanımına da olanak sağlamaktadır. Silisyum nanoyapı elde etmek için farklı yöntemler olsa da işlemin basit ve düşük maliyetli olması ve de herhangi bir şekil ve boyuttaki silisyum alttaşa uygulanabilirliği avantajlarından dolayı metal-destekli kimyasal aşındırma (MACE) yöntemi oldukça popülerdir ( $\mathrm{Li}$ ve Bohn, 2000; Zhang ve ve ark., 2008). Bu yöntem, katalizör olarak davranan metal parçacıkların silisyum yüzeyinde birikerek asidik bir çözelti içerisinde silisyumun aşındırılması ve sonuç olarak nanoyapı elde edilmesi esasına dayanır. $\mathrm{Bu}$ çalışmada desenlendirilmiş n-tipi $\mathrm{Si} \quad(d-\mathrm{Si})$ alttaşı üzerine nanoyapı elde etmek için uygulanan MACE yöntemi şematik olarak Şekil 3'te verilmiştir.

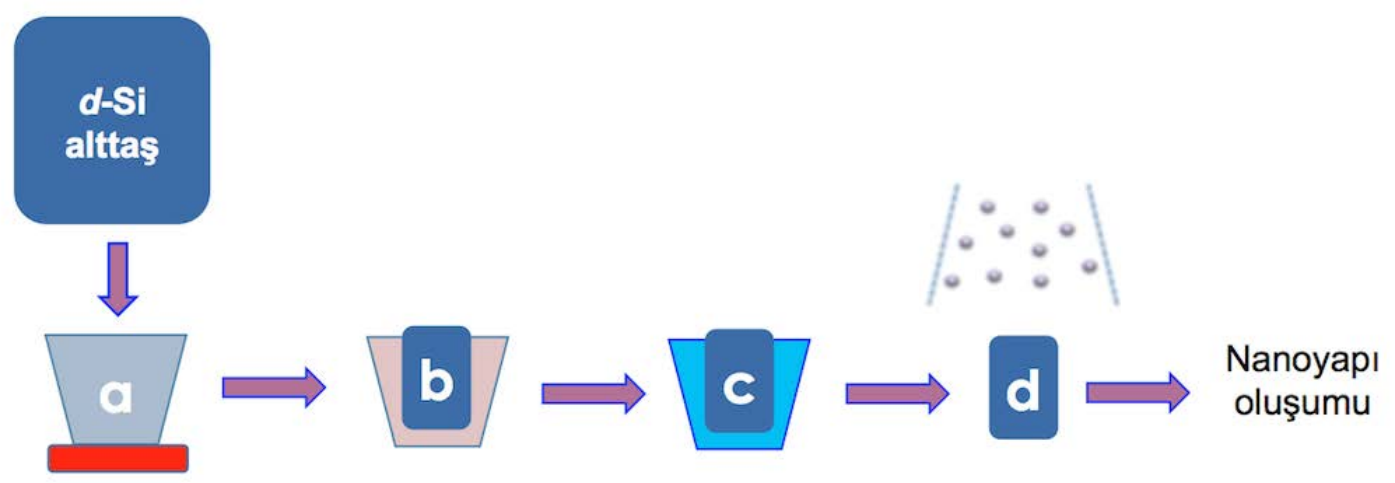

Şekil 3. Desenlendirilmiş n-tipi Si ( $d$-Si) alttaşı üzerine nanoyapı elde etmek için uygulanan MECA yönteminin şematik gösterimi. İşlemler sırası ile şu şekildedir; aşındırma işlemi (a), Ag tabakayı temizleme işlemi (b), numuneyi yıkama (c) ve kurutma aşaması (d). 
Şekil 3'te ayrıntıları verildiği gibi nanoyap1 sentezi için ilk olarak $d$-Si alttas $\mathrm{AgNO}_{3}$ ( $\left.0.102 \mathrm{gr}\right)$ ve $\mathrm{HF}(\sim 13.6 \mathrm{~mL})$ karışımından oluşan çözeltinin içerisine yerleştirilir ve $50^{\circ} \mathrm{C}$ sicaklıkta 60 dakika boyunca bekletilir. Bu esnada Ag katalizör nanoparçacıklar ve HF sayesinde nanoyapı oluşması beklenir. İkinci aşamada ise aşındırma işlemi sonrasında Ag tabakayı silisyum yüzeyinden temizlemek için $d$-Si alttaş $\mathrm{HNO}_{3}(\sim 18.5 \mathrm{~mL})$ içeren çözelti içerisinde oda sıcaklığında yarım saat bekletilir. Sonraki aşamada ise $d$-Si alttas yıkamak amacı ile saf su içerisinde yeterli süre boyunca birakılır. Son olarak, aşındırma işlemine maruz kalmış $d$-Si alttas $\mathrm{N}_{2}$ gazı ile kurutulur. $\mathrm{Bu}$ işlemler serisi sonrasında nanoyapı oluşumu gözlenir.

\section{Bulgular}

Pürüzsüz ve desenlendirilmiş Si alttaşlar üzerine kaplanmış yoğunluk modülasyonlu ve toplamda $660 \mathrm{~nm}$ kalınlığa sahip İTO ince filmlerin üst yüzey SEM görüntüleri Şekil 4'te gösterilmiştir. $\mathrm{Bu}$ kalınlıktaki İTO ince filmlerin morfolojik özellikleri daha belirgin olduğu ve daha ince numunelerle kendi sinıflarında benzerlik gösterdiği için sadece en kalın numunenin SEM görüntülerine yer verilmiştir. Pürüzsüz Si (p-Si) alttaşı üzerine kaplanan İTO filmleri morfolojik açıdan farklılık gösterirken desenlendirilmiş $\mathrm{Si}(d-\mathrm{Si})$ alttaş1 üzerindeki İTO filmler arasında göze çarpan bir farkl1lık gözlenmemektedir. Spesifik olarak, $p$-YA-330 olarak adlandirılan ve $p$-Si alttaşı üzerine önce $330 \mathrm{~nm}$ kalınlıkta YBPİTO ve sonrasında yine aynı kalınlıkta ABPITTO kaplayarak elde edilen numunenin oldukça pürüzsüz olduğu görülmektedir (Şekil 4a). Bunun aksine, p-AY-330 olarak adlandırılan ve bir önceki numune ile arasındaki tek farkın ABP-İTO ve YBP-İTO katmanların üretim sıralamasının tersi olduğu numunenin yüzeyinde ise nanoyap1 benzeri oluşumlar göze çarpmaktadır (Şekil 4b).

$\mathrm{Bu}$ farklılığın nedeni YBP ile üretilen filmin pürüzlü bir yapıya sahip olması ile açıklanabilir. Yüksek basınçta hedeften kopartılan atomlar ile Ar gazı atomları arasındaki gerçekleşen yüksek çarpışma oranı sebebi ile hedef atomları alttaşa geniş açılarda ulaşır ve sonuç olarak daha gözenekli ve pürüzlü bir mikro yapıya sahip ince film üretimi gerçekleşir (Scofield ve ark., 1995).

$\mathrm{Bu}$ açıklamanın 1şı̆̆ında üst katmanı yüksek basınç altında kaplanan numunenin pürüzlü yapısı anlam kazanırken neden aynı etkinin alt katmanı yüksek basınç altında kaplanan numunede gözlemlenemediği sorusu akla gelebilir. Bunun nedeni ise pürüzlü yapının üstüne basınç altında kaplanan katmanın pütürleri kapatarak numune yüzeyini son derece pürüzsüz hale 
getirmesi olarak verilebilir. ABP ile üretilen filmin YBP ile üretilene göre daha yoğun ve gözeneksiz olması da (Assunçao ve ark., 2003) morfolojik yapıdaki bu farklılı̆̆ açıklamada yardımcı olabilir. Pürüzsüz Si alttaş kullanıldığında görülen bu farklılık desenlendirilmiş Si alttaş için söz konusu
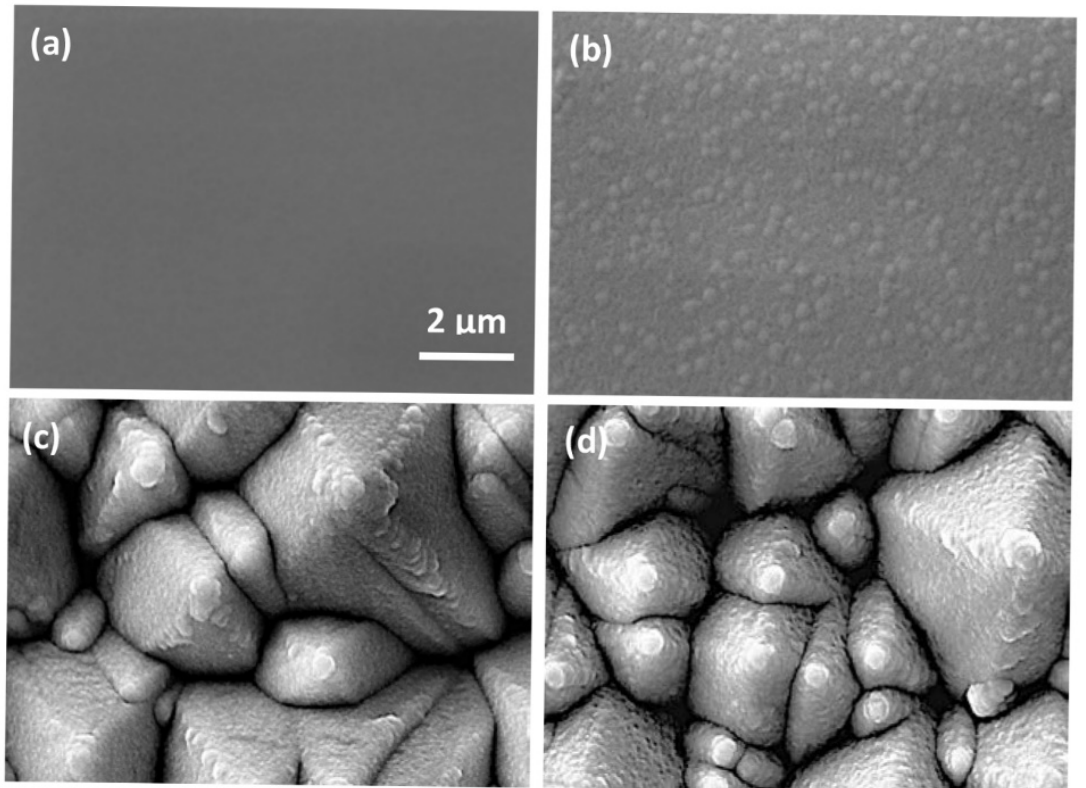

Şekil 4. Pürüzsüz Si ( $p$-Si) ve desenlendirilmiș $\mathrm{Si}(d-\mathrm{Si})$ alttaşları üzerine yoğunluk modülasyonlu İTO ince film numunelerin üst yüzey SEM görüntüleri, sırası ile; $p$-YA-330 (a), p-AY-330 (b), $d$-YA-330 (c) ve $d$-AY-330 (d).

Üretim esnasında kullanılan basınç değeri İTO ince filmlerin morfolojik yapısının yanı sıra optik özelliklerini de etkiler. Yoğunluk modülasyonlu İTO numunelerin optik özelliklerini incelemek için cam alttaş üzerindeki filmlerin geçirgenlik (Şekil 5) ve $p$-Si alttaş üzerindeki filmlerin yansıma (Şekil 6) ölçümleri gerçekleştirilmiştir. Şekil 5'te gösterildiği gibi İTO filmlerin kalınlık değeri artıkça beklendiği gibi geçirgenlik azalır. değildir. $\mathrm{Bu}$ durum, desenlendirilmiş $\mathrm{Si}$ yüzeyindeki piramit yapıların yüksek ve alçak basınç ortamında hedef atomlarının kırdığ ve bariz bir fark oluşturmadığı söylenerek açıklanabilir. geliş açısının morfoloji üzerindeki etkisini

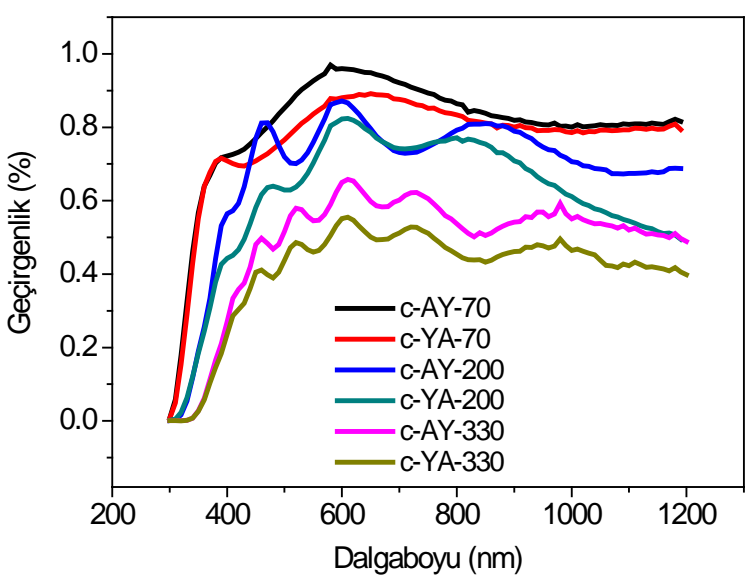

Şekil 5. Cam alttaşı üzerine kaplanmış yoğunluk modülasyonlu İTO ince film numunelerin geçirgenlik ölçüm sonuçları. 
Aynı zamanda kalınlık artmasına bağlı olarak geçirgenlik eğrisindeki tümsek ve çukurların da artması ince filmlerde kalınlığa bağlı olarak görülen girişimin sonucudur. Bu grafikte göze çarpan bir diğer önemli sonuç ise tüm ince film kalınlık değerlerinde üst katmanı yüksek basınç altında üretilen numunelerin daha yüksek geçirgenliğe sahip olmasıdır. YBP ile üretilen filmin daha az yoğunluğa sahip olması ve ilk olarak bu tabaka ile karşılaşan 1şığın daha az yansımaya uğrayarak yüksek oranda malzemenin içinden geçmesi bu gözlemin sebebi olarak verilebilir. Bir sonraki yansıma grafiklerinden elde edilen bulgular da bu sonucu destekler niteliktedir.

Pürüzsüz Si (p-Si) üzerine kaplanmış İTO numunelerin 1şığın farklı geliş açılarında ölçülmüş yansıma grafikleri Şekil 6'da verilmiştir. Morfolojik karakterizasyonda olduğu gibi yansıma ölçümleri de diğer kalınlık değerleri ile benzerlik gösterdiğinden bu kısımda orta kalınlıktaki numuneler üzerinden gerçekleştirilen sonuca yer verilmiştir. Grafiklerdeki çukur ve tümsekler bir önceki durumda olduğu gibi 1şığın girişimi sonucu oluşan bir durumdur. Ölçüm aralığı olan UV-VIS-NIR spektrumunun hemen hemen tüm kısmında ve bütün açı değerlerinde üst katmanı yüksek basınç altında üretilen İTO numunesi ( $p$-AY-200) daha düşük yansıma özelliği göstermiştir. Bunun nedeni ise YBP ile üretilen ince filmin gözenekli yapısından dolayı malzeme yoğunluğunun azalması ve sonuç olarak daha düşük bir kırılma indisine sahip olarak kendiliğinden yansıma önleyici kaplama (ARC) olarak davranmasıdır (Keles ve ark., 2017; Keles ve ark., 2016). Ayrıca, YBP filmin yüzeyinin de daha pürüzlü olması yine yüzeyden yansımayı azaltmaya yönelik bir özelliktir. Üstelik bu sonucun 1şı̆̆ın tüm geliş açı değerlerinde sağlanması da (Şekil 6a,b,c) YPB-İTO katmanın çok yönlü ARC olarak kullanılabileceğini gösterir. 

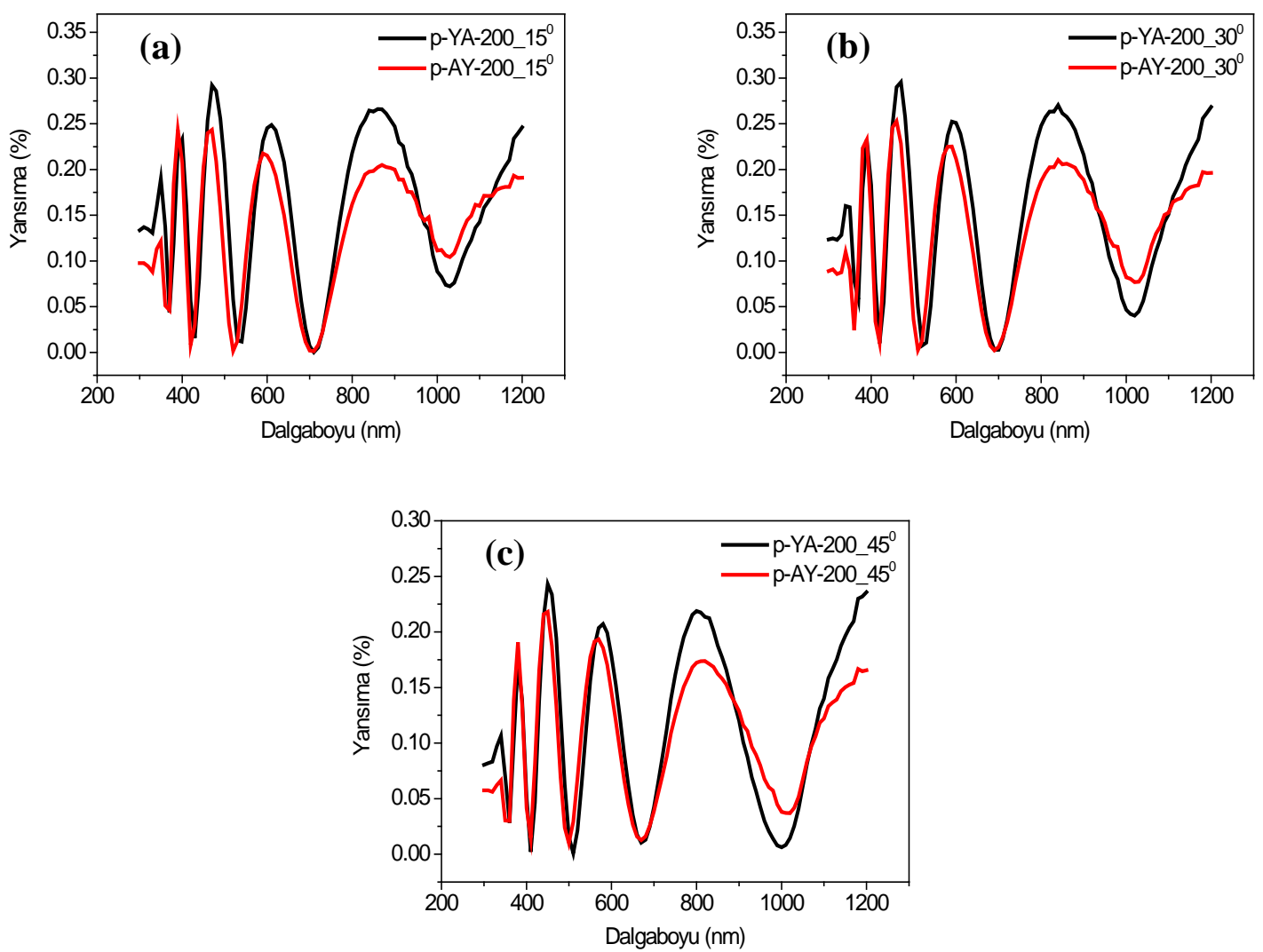

Şekil 6. Pürüzsüz Si (p-Si) alttaşı üzerine kaplanmış yoğunluk modülasyonlu İTO ince film numunelerin yansıma ölçüm sonuçları; $15^{\circ}$ lik geliş açısı altında (a), $30^{\circ}$ 'lik geliş açısı altında (b) ve $45^{\circ}$ 'lik geliş açısı altında (c).

Sonuç olarak, aynı kalınlık ve üretim yoğunluk modülasyonlu İTO ince film koşullarına rağmen sadece yüksek ve alçak numunenin üst katmanını YBP ile üretmenin basınç değerlerinde elde edilen katmanların geçirgenliği artırdığı ve paralel olarak sıralanışının değiştirilmesi ile optik yansımayı düşürdüğü yani optik özellikleri özelliklerin de kayda değer bir şekilde iyileştirdiği gösterilmiştir. değiştiği gözlemlenmiş̧tir. Spesifik olarak, 

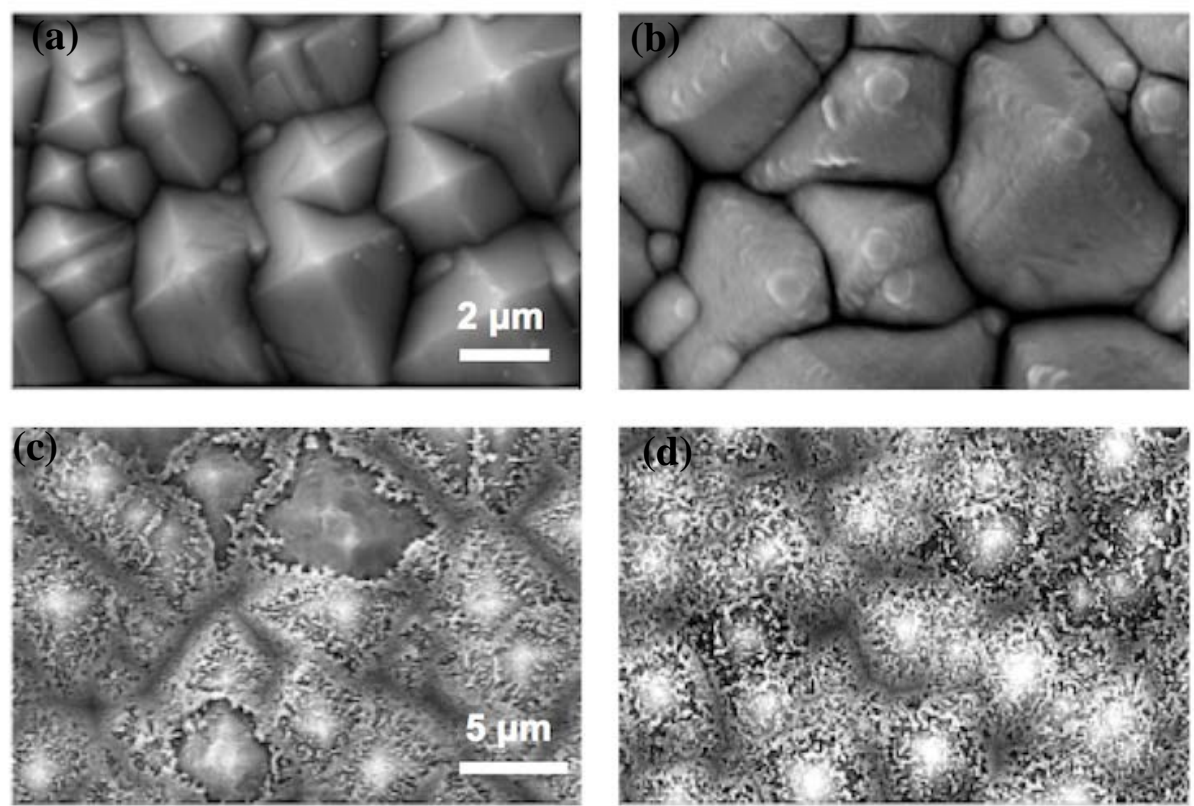

Şekil 7. Yalın (a) ve YBP-İTO kaplanmış (b) desenlendirilmiş Si (d-Si) alttaşları üzerine sentezlenmiş nanoyapılar. Nanoyapı oluşumu homojen olarak elde edilememişken (c) YBP-İTO üzerine sentezlenen nanoyapılar oldukça homojen görünmektedir (d).

Son olarak, YBP-İTO ince filmin nanoyapı oluşumunu nasıl etkilediği incelenmiştir. Bahsedildiği gibi Si tabanlı güneş hücrelerinde verimi artırmak amacı ile nanoyapı kullanımı oldukça yaygındır. $\mathrm{Bu}$ sebeple, üzerine herhangi bir işlem yapılmamış ve YBP-İTO kaplanmış desenlendirilmiş $d$-Si alttaşları üzerine aynı şartlar altında MACE yöntemi ile nanoyapı sentezi gerçekleştirilmiştir. Elde edilen nanoyapıların ve alttaşların üst yüzey SEM görüntüleri Şekil 7'de verilmiştir. Şekil 7c ve $7 d$ 'de net bir şekilde görüldüğü gibi YBP-İTO üzerine sentezlenen nanoyapılar homojen bir oluşum gösterirken yalın $d$-Si üzerine nanoyapı oluşumu tam olarak gerçekleşememiştir. Bunun nedeni yine YBP-İTO’nun pürüzlü yapısı sayesinde aşındırıcı çözeltiyi piramit yapılar üzerinde daha iyi tutması ve sonuç olarak daha etkili bir aşındırma süreci ile açıklanabilir.

\section{Tartıșma}

$\mathrm{Bu}$ çalışmada yükssek basınç püskürtme yönteminin yoğunluk modülasyonlu ince film numunelerin morfolojisini değiştirdiği ve buna bağl1 olarak optik özelliklerini iyileştirdiği gösterilmiştir. Üst tabaka ince filmi yüksek basınç altında elde edilen numune pütürlü bir yapıya sahip olurken malzeme miktarınca özdeş ama tek fark1 üst tabaka ince filmin alçak basınç altında üretilmesi olan numune daha pürüzsüz bir yüzey yapısına sahiptir. Buna bağlı olarak YBPİTO üst tabakalı ince filmin her kalınlık değeri için daha yüksek geçirgenlik sergilediği gözlemlenmiştir. $\mathrm{Bu}$ bulguyu 
destekler nitelikte olarakta bu numunelerin yüzeyden yansıma özelliğinin daha düşük olduğu gösterilmiştir. Üstelik yüzeyden yansımanın azalması bulgusunun gelen 1şığıı üç farklı geliş açısı içinde sağlanıyor olması yoğunluk modülasyonlu ince film numunelerde YBP ile üretilen üst katmanın güneş hücrelerinde çok yönlü yansıma önleyici kaplama olarak kullanılabileceğini öngörmektedir. Desenlendirilmiş Si alttaş üzerine üretilen YBP-İTO filmin sentezlenen nanoyapıların daha homojen elde edilmesi ile sonuçlanması ise yine güneş hücrelerinde bir avantaj olarak ele alınabilir. Sonuç olarak basit ama etkili olan YBP yöntemi ile hem yansıma önleyici kaplama hem de homojen nanoyap1 üretimi için uygun bir zemin olan İTO üretiminin mümkün olduğu bu çalışmada gösterilmiştir. $\mathrm{Bu}$ çalışmada elde edilen bilgiler 1şığında ise YBP yöntemi ile elde edilen İTO sayesinde Si tabanlı güneş hücresinin verimliliğinin artırılabileceğini ifade etmek gerçekçi olacaktır.

\section{Teşekkür}

$\mathrm{Bu}$ çalışma Niğde Ömer Halisdemir Üniversitesi Nanoteknoloj Uygulama ve Araştırma merkezi bünyesinde gerçekleştirilmiştir.

\section{Kaynaklar}

Assunçao V, Fortunato E, Marques A, Aguas H, Ferreira I, Costa MEV, Martins R (2003). Influence of deposition pressure on the properties of transparent and conductive ZnO:Ga produced by r.f. sputtering at room temperature. Thin Solid Films 427: 401405.

Conibeer G, Green M, Corkish R, Cho Y, Cho E-C, Jiang C-W, Fangsuwannarak T, Pink E, Huang H, Puzzer T, Trupke T, Richards B, Shalav A, Lin K-L (2006). Silicon nanostructures for third generation photovoltaic solar cells. Thin Solid Films 511-512: 654-662.

Ferry VE, Sweatlock LA, Pacifici D, Atwater H (2008). Plasmonic nanostructure design for efficient light coupling into solar cells. Nano Lett 8: 4391-4397.

Gheidari AM, Soleimani EA, Mansorhoseini M, Mohajerzadeh S, Madani N, Shams-Kolahi W (2005). Structural properties of indium tin oxide thin films prepared for application in solar cells. Materials Research Bulletin 40: 1303-1307.

Gordon, RG (2000). Criteria for choosing transparent conductors. Mrs Bulletin 52-57.

Hussain, SO, Oh W-K, Ahn S, Tuan Le, AH, Kim S, Lee Y, Yi J (2014). RF Magnetron sputtered indium tin oxide films with high transmittance and work function for a$\mathrm{Si}: \mathrm{H} / \mathrm{c}-\mathrm{Si}$ heterojunction solar cells. Vacuum 101: 18-24.

Keles F, Badradeen E, Karabacak T (2017). Self-anti-reflective density-modulated thin films by HIPS technique. Nanotechnology 28: 335703. 
Keles F, Cansizoglu H, Badraddin EO, Brozak MT, Watanabe F, Karabacak T (2016). HIPSGLAD core shell nanorod array photodetectors with enhanced photocurrent and reduced dark current. Mater Res Express 3: 105028.

Kim N, Um H-D, Choi I, Kim K-H, Seo K (2016). 18.4\%-Efficient heterojunction Si solar cells using optimized ITO/Top electrode. ACS Appl Mater Interfaces 8: 11412-11417.

Li X, Bohn WP (2000). Metal-assisted chemical etching in HFÕH2O2 produces porous silicon. Appl Phys Lett 77: 2572.

Lien SY (2010). Characterization and optimization of ITO thin films for application in heterojunction silicon solar cells. Thin Solid Films 518: 10-13.

Masuko K, Shigematsu M, Hashiguchi T, Fujishima D, Kai M, Yoshimura N, Yamaguchi T, Ichihashi Y, Mishima T, Matsubara N, Yamanishi T, Takahama T, Taguchi M, Maruyama E, Okamoto S (2014). Achievement of more than 25\% conversion efficiency with crystalline silicon heterojunction solar cell. IEEE Journal of Photovoltaics 4: 1433.

Schirone L, Sotgiu G, Califano FP (1997). Chemically etched porous silicon as an antireflection coating for high efficiency solar cells. Thin Solid Films 297: 296-298.

Scofield JH, Duda A, Albin D, Ballard BL, Predecki PK (1995). Sputtered molybdenum bilayer back contact for copper indium diselenide-based polycrstalline thin-film solar cells. Thin Solid Films 260: 26-31.

Tsakalakos L, Balch J, Fronheiser J, Korevaar BA, Sulima O, Rand J (2007). Silicon nanowire solar cells. Appl Phys Lett 91: 233117.

Yoshikawa K, Kawasaki H, Yoshida W, Irie T, Konishi K, Nakano K, Uto T, Adachi D, Kanematsu M, Uzu H, Yamamoto K (2017). Silicon heterojunction solar cell with interdigitated back contacts for a photoconversion efficiency over 26\%. Nature Energy 2: 17032.

Zhang ML, Peng K-Q, Fan X, Jie J-S, Zhang R-Q, Lee S-T, Wong N-B (2008). Preparation of large-area uniform silicon nanowires arrays through metal-assisted chemical etching. $J$ Phys Chem C 112: 4444-4450.

Zhao L, Zhou Z, Peng H, Cui R (2005). Indium tin oxide thin films by bias magnetron rf sputtering for heterojunction solar cells application. Applied Surface Science 252: 385392.

Zhong S, Liu B, Xia Y, Liu J, Liu J, Shen Z, Xu Z, Li C (2013). Influence of the texturing structure on the properties of black silicon solar cell. Solar Energy Materials 108: 200204. 